\title{
CURAÇAO TEGEN HET EINDE DER WEST-INDISCHE COMPAGNIE \\ DOOR
}

\author{
Mr. B. DE GAAY FORTMAN.
}

Het is bekend, dat de tweede West-Indische Compagnie eigenlijk nooit gebloeid heeft. „Geldgebrek” was „een vitium originis der tweede Cie", ${ }^{1}$ ) en vooral had zij geld noodig na den vierden Engelschen oorlog. Reeds meermalen was in de vergadering der Staten-Generaal de toestand der Compagnie en die van hare bezittingen ter sprake gekomen, en over eene hervorming overleg gepleegd. In de vergadering van 27 Augustus I788 viel daaromtrent een besluit, en op den laatsten dag van dat jaar vermelden de Resolutiën van dit college, dat ingekomen is een brief van den Prins van Oranje, Willem V, opperbewindhebber der Compagnie, inhoudende, dat deze, ,ingevolge van haar Hoog. Mog. Resolutie van 27 Augustus laatstleeden" tot zijne Commissarissen had benoemd de-heeren Grovestins en Boey.

Jhr. Willem August Sirtama thoe Grovestins, gedeputeerde van Friesland ter vergadering van H.H.M.M., en Mr. W. C. Boey, schepen en raad der stad Haarlem, zijn als „Commissarissen naar de West-Indische Eilanden en de Colonien Essequebo en Demerary", vergezeld van Mr. Rochus van Suchtelen als secretaris, spoedig daarheen vertrokken. Voor uitrustingskosten ontvingen de commissarissen ieder $f 5.000$, de secretaris moest met $f$ I.500 genoegen nemen, de daggelden voor Commissarissen bedroegen $f 40$, voor den secretaris $f$ I5.

In het Rijksarchief bevindt zich een afschrift van het Rapport aan Zijne Doorluchtigste Hoogheid den Heere Prince van Oranje en Nassau etc. etc. etc., overgegeven van wegen Hoogstdeszelfs Commissarissen naar de Kolonien van den Staat in de West-Indiën betreffende het eiland Curaçao". Blijkens het onderschrift zou dit in I857 zijn ,afgeschreven naar eene gelijktijdige kopy,.... berustende onder den heer Generaal

1) S. v. B. in de Encyclopaedie van Nederlandsch West-Indiē blz. 224 
Majoor Baron van Raders'”1). De talrijke bijlagen, naar welke het rapport verwijst, zijn niet aanwezig.

Publicatie van het geheele rapport zou meer tijd en plaatsruimte vergen, dan waarop verscheidene minder beteekenende gedeelten aanspraak mogen maken; evenwel komt het ons voor, dat het stuk genoeg belangrijks bevat, om openbaar gemaakt te worden. Hamelberg heeft er in zijn De Nederlanders op de West-Indische eilanden ${ }^{2}$ ) hier en daar iets uit meegedeeld. Wij geven er de voorkeur aan, in het onderstaande in den regel de woorden van het rapport te volgen, en in de aanteekeningen nu en dan eenig commentaar te geven.

I9 Augustus I789 van de koloniën aan de vaste kust vertrokken, kwamen Commissarissen den laatsten dag dier maand in de haven van Curaçao, „na onderweg de bezaansmast te hebben verloren en in groot gevaar geweest te zijn van de groote mast mede te verliezen".

Was in Demerary en Essequebo hunne taak geweest, eene geheel nieuwe bestuursregeling, die beide gebieden tot één kolonie vereenigde, tot stand te brengen ${ }^{3}$ ), omtrent de eilanden was in de boven vermelde vergadering der Staten-Generaal van 27 Augustus I788 bepaald, ,dat de regeering.... provisioneel zoude blijven op den ouden voet". Wat Curaçao betreft, stelden Commissarissen zich ten doel, na te gaan „waar uit eigentlijk de alhier plaatshebbenden oneenigheden [,welke alhier zedert zoo langen tijden tusschen de Leden van de Regering en tusschen de Ingezetenen hadden plaats gehad'] waren voortgesproten, wat de Regering gedurende dezelve had in het werk gesteld, en wat als nu verrigt behoorde te worden om de goede rust te herstellen, die Regering wederom klem

1) Taal en stijl zijn lang niet overal onberispelijk. Waarschijnlijk is dit in vele gevallen aan de onkundigheid van den afschrijver te wijten.

$\left.{ }^{2}\right)$ Ook in „Een veelbewogen tijdperk” (I796-I804), Eerste Jaarlijksch Verslag van het geschied-, taal-, land-en volkenkundig genootschap, gevestigd te Willemstad, Curaçao. Hamelberg noemt daar en elders Boey: W. G. de Boey en geeft aan Sirtama thoe Grovestins de voorletters A. J.

G. J. Simons, Beschrijving van het eiland Curafou. Oosterwolde, I868, schijnt het rapport ook gekend te hebben, maar noemt Thoe Grovestins, A. J. van Grovenstein.

3) P. J. Blok, Geschiedenis van het Nederlandsche volk, 2e druk. III, blz. 654 . 
te geven en de Ingezetenen tevrede te stellen". Om dit doel te bereiken begon de Commissie met op vastgestelde dagen en uren audientie te verleenen aan ieder, die daarvan gebruik wilde maken, terwijl ook verschillende schriftelijke klachten door haar werden in ontvangst genomen.

De oorsprong van de genoemde oneenigheden, zeggen Commissarissen, moet niet als in Demerary gezocht worden in een misnoegen van de „meeste en voornaamste” ingezetenen over de regeering van de bewindhebbers der West-Indische Compagnie of over de uitvoering harer bevelen door hare ambtenaren, maar veeleer in eene zwakheid van Directeur ${ }^{1}$ ) en Raden, die zich de teugels uit handen hebben laten wringen. In I784, toen de overmatige winsten, waaraan men gedurende den oorlog 2 ) was gewoon geweest, door den pas gesloten vrede eensklaps ophielden, moet men de eerste bron van dit misnoegen der ingezetenen zoeken. Directeur en Raden hadden in dat jaar op voorstel van zekeren advocaat Hessen, die, in I783 aangekomen, ,zich door zijne particuliere kundigheden een grooten invloed (had) weten te bezorgen", een nieuwe manier van procedeeren ingevoerd, die grootendeels ontleend was an die van ${ }^{580}$ in Holland, en ten koste van de rechtzoekenden veel duurder was dan de bestaande ,zo ten behoeve van de practizijns als van het secretaris en Bodenscomptoir".

Waren Directeur en Raden hiermee hunne bevoegdheid te buiten gegaan, daar zij gehandeld hadden ,zonder last of approbatie van den Souverein of van bewindhebberen", meer afkeuring nog verdient, naar het oordeel van Commissarissen, de houding van het Bestuur tegenover het verzet der burgerij, dat naar aanleiding van deze verandering in het procesrecht ontstond. Aan het einde van I785 werd door ,een menigte, waaronder verscheidene notabele ingezetenen", vernietiging, althans alteratie, van de nieuwe ordonnantie verzocht, en voorts vrij-

\footnotetext{
1) Gouverneur was toen Johannes de Veer (I782-I796). De in de Encyclopacdie van Nederlandsch-West-Indie bladz. 328 gegeven jaartallen voor dezen Gouverneur, $I 782-\mathrm{I} 784$, zijn niet juist. Jan Jacob Beaujon was alleen eenige maanden in 1796 Gouverneur en niet van $1784-1796$. Zie Hamelberg t.a.p. bladz. 24 e.v.

2) De Amerikaansche vrijheidsoorlog ( $\mathrm{I} 776-\mathrm{I} 783)$. In dien tijd noemde J. H. Hering Curaçao „een klein Paradijs van aardschen overvloed." Beschrijving van het eiland Curafao enz. Amsterdam 1779.
} 
heid voor den justiciabel, „om in de materie van schuldvordering en diergelijke liquide pretentien zijn eigen zaak voor te dragen", en eindelijk vermindering van het salaris van praktizijns. Met de beschikking op dit verzoek niet voldaan, wezen de ingezetenen den $3^{\text {den }}$ Januari I 786 twaalf ,gecommitteerden" aan, om voor hen op te treden. In hunne volmacht kwamen de volgende woorden voor: „Insgelijks met macht om zich te verzetten teegens alle obstaculen en refusen, die huned: tendeezen, onverhooplijk, mogten ontmoeten, en generalijk om zoo in dit als alle andere opzigten de beste middelen tot de beste eindens voor het algemeen welzijn in het werk te stellen, onder verband als naar rechten".

Commissarissen raken haast niet uitgepraat over de „onvergeeflijke onvoorzigtigheid" van Directeuren en Raden, om deze gecommitteerden als zoodanig te erkennen, en met hen te onderhandelen, zelfs zonder aanmerking te maken op de aangehaalde woorden. Het gevolg van deze handelwijze van het Bestuur is geweest, dat Directeur en Raden, van wie de ,burgerraad" Hansen $^{1}$ ) openlijk de partij der gecommitterden nam, „dagelijks met adressen geplaagd" werden van deze zijde. Zoo ging het door, tot in I786 de advocaat Hessen, die als „,berokkenaar van het kwaad" werd aangemerkt, en het niet langer kon uithouden, het eiland verliet.

Voor het uiterlijk was het toen vrij kalm, maar in stilte werd er gekuipt. Zoo zaten de Directeur en de Kerkeraad elkaar dwars. De laatste maakte moeilijkheden met het afgeven van eene attestatie aan den secretaris Mr. Petrus Bernardus van Starkenborgh, die naar Europa zou gaan, ,gedeeltelijk om de belangens der regering in de voormelde geschillen waar te nemen en gedeeltelijk om te ontgaan den haat der ingezetenen, waarin hij rijkelijk deelde"²). De Kerkeraad trad „verschrikkelijk

1) Misschien Hansz. Simons t.a.p. (en ook A. T. Brusse, Curafao en zijne bewoners, Curaçao I882 blz. 90, die hier eigenlijk Simons excerpeert) beweert, dat de advocaat Hessen de partij der burgers koos. Dat kan niet juist zijn, daar het optreden der burgerij juist tegen de door Hessen uitgelokte verandering van het procesrecht ging.

2) Niettemin was hij later geruimen tijd fiscaal en trad zelfs bij het overlijden van Gouveneur-Generaal Kikkert als zoodanig op van I8I9-I820. P. A. Euwens O. P. „Curaçao in $\mathrm{r} 8 \mathrm{o}_{3}-\mathrm{r} 804$ ", Onze Eeuw rgo8. Zie ook mijn "De inbezitneming van Curaçao in 1816" in het Tijdschrift voor Geschiedenis, Land-en Volkenkunde, I9I4 afl. 2. Simons noemt hem t. a. p. Starrenburg, en zegt, dat hij niet minder gehaat was dan de advocaat Hessen. 
partijdig en haatelijk op" tegen den secretaris, terwij1 uit weerwraak de Directeur een diaken, den advocaat Amalry, niet wilde erkennen, omdat hij geen attestatie uit Holland had meegebracht, hoewel eerst diens aanstelling door hem was geapprobeerd.

Maar het ergst maakten Directeur en Raden het in zake de moeiten, die men den fiscaal Mr. Pieter Theodorus van Teylingen aandeed. Deze werd o.m. van malversaties beschuldigd. Zonder eenig bewijs werden deze klachten en die over zaken, ,welke hem in geenen deele concerneerden", bij den Raad ingebracht; zelfs verzochten ,drie zoogenaamden oudsten des volks, die buiten hunnen ouderdom zeekerlijk niets eerwaardigs hadden”, „dat de fiscaal mogte worden gedemitteerd”, daarbij te kennen gevende „hem niet langer als fiscaal te kunnen erkennen, uithoofde van de conduite, die hij ten nadeele van het algemeen welzijn hieldt".

De aanhang van de beschuldigers ${ }^{1}$ ) vermeerderde met den dag. Drie personen, die zich aan het hoofd van eene tegenbeweging wilden stellen, werden mishandeld, en toen dit ongestraft gelaten werd, nam de brutaliteit van hen, die den fiscaal weg wilden hebben, dermate toe, dat Directeur en Raden niet beter wisten te doen dan toe te geven, en I8 October I787 den fiscaal schorsten, zooals zij zelf zeggen ,vermits zij daartoe om politique redenen genoodzaakt waren" ${ }^{2}$ ). Commissarissen spreken hier van ,eene kinderachtige vrees voor zijne (des fiscaals) beschuldigers en derzelver aanhang", en meenen, dat het gedrag van Directeuren en Raden althans den schijn van partijdigheid tegen den fiscaal draagt. De deurwaarder en gerechtsbode werd provisioneel tot fiscaal aangesteld, en een apothekersbediende tot deurwaarder en gerechtsbode. I5 Juli

1) Uit het verzoek van den fiscaal om rechtsherstel aan de StatenGeneraal zijn hunne namen bekend, t.w. Adriaan Webb en diens schoonzoon Gerardus Duykinck, Pieter François Diedenhoven (over dezen rijken grondeigenaar zie men Hamelberg t. a. p. bladz. 65 en 66), Cornelis Berg. Johannes Stuylingh Corneliszoon, Jan Hansz, Cornelis Raven Hansz, Christiaan Geerman, Johannes Mathias Gähne, Coenraad Siebert en Aaron Aillion.

2) Of zooals Hamelberg t. a. p. bladz. 47 meedeelt: „op de afverging en aandrang van een aantal burgers en ingezetenen alhier, zich opdoende als een volksstem". 


$$
446
$$

I788 werd de fiscaal ,uit kragte van een mandement van Maintenu van H.H.M."' hersteld in zijn post ${ }^{1}$ ).

De laatste kwestie, die Commissarissen vermelden, is die van de aanstelling van den burger-kapitein Striddels, welke niet met instemming der Regeering geschiedde, doch het gezag van deze en het ontzag voor haar was verdwenen. Zelfs werd bij de aanstelling van Striddels door zijne burgers een eed op de wacht aan hem gedaan, ,welke direct aanliep tegen de gehoorzaamheid aan de regeering verschuldigd". Meer wordt hiervan niet vermeld.

Ten slotte spreken Commissarissen er hunne afkeuring over uit, dat de notulen van den grooten raad sedert I784 niet gehouden bleken ${ }^{2}$.

Commissarissen zullen wel wat vreemd hebben opgezien, toen zij onder de bij hen ingediende schriftelijke klachten ook eene memorie van Directeur en Raden aantroffen. Het lijkt echter geen onhandige manoeuvre van dit college, om van dit middel door Commissarissen den misnoegden aan de hand gedaan, gebruik te maken, om de aandacht van zichzelf af te leiden. De bom sprong echter verkeerd, want aldus rekenden Commissarissen met deze klagers en hunne klachten af :

Vooreerst bevonden zij, „dat zeer veele zaken zonder eenigen grond waren voorgesteld, als bij voorbeeld, wanneer de raad zich beklaagde over het gedrag van de gecommitteerdens ${ }^{3}$ ), moest natuurlijk het antwoord zijn de vrage, waarom zij dezelve als zoodanig hadden erkend? waarom zij de voormelde acte van qualificatie hadden goedgekeurd? waarom zij rekeningen in handen van die gekwalificeerdens ter examen hadden gesteld, even of het een behoorlijk college was ? waarom zij dezelven telkens in den raad hadden geadmitteerd, en zelfs als

1) Hamelberg meent t. a. p. minder juist, dat dit het gevolg was van het onderzoek van Grovestins en Boey, en deelt verder mee, dat eenigen tijd later Van Teylingen zich weer het ongenoegen van een groot aantal ingezetenen op den hals haalde, en I9 Augustus 1797 andermaal door den Raad ontslagen werd. Aldus ook Simons t. a. p. bladz. 49.

$\left.{ }^{2}\right)$ Hamelberg heeft in het geheel geen notulen van dit college gevonden buiten de in het Eerste Jaarverslag gepubliceerde van I7I3. Zie De Nederlanders op de West-Indische eilanden, bladz. I86.

s) In zake de verandering van het procesrecht. 
waren het leden van dien stoelen had doen geven ?1) en waarom zij niets hoegenaamd in het werk hadden gesteld om dat alles tegen te gaan ? al verder kon men niet nalaten aan dien raad onder het oog te brengen, dat wanneer zij zich gehouden hadde, en niet vergeten ware geweest Hunne Hoog Mogende resolutie van den I9 December I766, zij dan niet zoude hebben te klagen over de injurieuse rekwesten, schrifturen en andere beleedigende handelwijzen, vermits geene publicatie in sterkere termen konde stellen dan dezelve was, en de souvereine hun dus gemagtigd had, om zich daaromtrent regt te verschaffen.... Even ongefundeerd was de beschuldiging van inactiviteit, den fiscaal te laste gelegd, want men had denzelven niet gemaintineerd in zijn post, maar aan de woede van een zaamgerotten hoop overgelaten, en op zijne herhaalde verzoeken niet gedisponeerd, toen het tijd was. Veele andere zaken waren bij de voorschreven memorie zonder eenig bewijs voorgedragen, en wat voor staat konde men derhalve op die voorgevens maken, temeer daar de notulen van den raad of geen gewag daaromtrent maken, of met zoo weinig oplettendheid waren gehouden, dat men geen het minste vertrouwen op dezelve konde stellen".

De maatregelen, door Commissarissen genomen, zijn de volgende : de advocaat Almary, die wel reden tot klagen had, o.a. omdat men hem verboden had, de titel te voeren van advokaat voor den Hove van Holland en West-Friesland en als "diacon" dwars had gezeten (zie hiervoor), maar tegen wien ook klachten bestonden als kerkeraadslid, en deze, dat hij zich „van de zoogenaamde gequalificeerdens en die van hun aanhang had bediend" (dus tegen zijn collega Hessen), en ten slotte, dat hij „aan twee kanten tegelijk als advokaat had gediend”,

1) Men kan moeilijk ontkomen aan den indruk, dat Commissarissen in deze zaak toch wel wat overdrijven in hunne verwijten aan Directeur en Raden. Het was nog geen 40 jaar geleden, dat onder Gouverneur Faesch de X zelf aan de burgerij voorgesteld hadden, om uit haar midden gecommitteerden te benoemen, die met bewindhebberen en den Directeur zouden raadplegen, om de bestaande geschillen op te lossen. Dit had toen een goed resultaat gehad. Hamelberg, De Nederlanders opde West-Indische eilanden, bladz. $160 / \mathrm{r}$. In meer dan een opzicht vertoonen de hier besproken toestanden overeenkomst met die onder Gouverneur Faesch; ook in den toestand, waarin, gelijk wij straks zullen zien, justitie en belastingwezen verkeerden. 
werd „de balie ontzegt”, evenals aan zijn collega Spencer „uithoofde van zijne beledigende schrifturen"1).

Van den burgerraad Hansen wordt nog het gedrag afgekeurd maar van een maatregel tegen dezen genomen blijkt niet. De advocaat Hessen had zich door de vlucht aan de gerechtigheid onttrokken.

Ook tegen de "gecommitteerden” werd door Commissarissen opgetreden. Zij achtten dit noodig, ook om een einde te maken aan de praatjes alsof de commissie "geen de minste magt had". Daar Directeur en Raden moeilijk tot rechter over dezen konden gesteld worden in eene gewone procedure, werd tot „eene provisionele politique dispositie" toevlucht genomen. De Parnassims van de Portugeesche Joodsche natie werden ontboden, en opmerkzaam gemaakt op art. 30 van hun Escamoth, waarbij aan de Joden werd verboden, eenige schrifturen te teekenen tegen hunne overheden op poene van excommunnie. De Parnassims werkten mee en de vijf Joden onder de gecommitteerden werden geëxcommuniceerd. Ten slotte deden zij boete en vroegen, „dat hun het gebeurde mogte vergeven worden, en belovende zich in het vervolg als gehoorzame ingezetenen te zullen gedragen, zonder zich ooit wederom met zaken van regering te bemoeijen". Voor Commissarissen was dit blijkbaar eene bevredigende genoegdoening.

Het meest hadden Directeur en Raden op hun geweten. Het was door hunne schuld, dat politie en justitie vervallen waren, „men had zich.... in de verbeelding gebragt van verscheiden privilegien te hebben". o.a. op het voorbeeld van Amsterdam meende men, ,dat geen burger of ingezeten door de Justitie in zijn huis vermogt te worden gehaald", zefs in het crimineele. Commissarissen makten wel aan die „,verbeelding” een einde, maar de geheele rechtsbedeeeling was niet veel zaaks; „de hooge raad in Holland zou getuigenis kunnen geven in welken fraaijen staat de procedures, welke uit het eiland Curaçao aldaar komen, bevonden worden". En wat de politie betreft: tal van "heilzame resolutien" waren in onbruik of vergeten, „en de raad was tot zoo een punt van lafheid vervallen, dat wanneer dezelve eene resolutie nam, welke slechts tegen den zin van eenige weinigen was, wierd dezelve of ingetrokken of niet

1) Wellicht dezelfde, die in 1797 bij het vernieuwde ontslag van $\mathrm{Mr}$. Van Teylingen provisioneel als fiscaal werd aangesteld. 
ten uitvoer gebragt”. „De conclusie van dit eerste gedeelte van het rapport zal dan ook niemand verwonderen, als Commissarissen daar schrijven : „Uit al het hiervoor ter nedergestelde blijkt dan ook van zelfs, dat bij de ondergeteekendens geene de minste bedenking viel, of de Directeur en de meeste Raden hadden verdiend afgezet en andere in hunne plaatsen gesteld te worden, maar daartoe deden zich zoo veel zwarigheden op, dat de ondergeteekenden dit werk voor hun onuitvoerlijk beschouwden"1). Zij meenden echter, dat „dit eiland eene geheel andere regering scheen te vorderen dan tot nu toe aldaar had plaats gehad".

De Groote Raad bestond uit den directeur, den secretaris en negen raden, t.w. de commissaris van de train, de commandant der militie, de commissaris van den slavenhandel, de capitein der burgerij, de eerste en de tweede officier van de militie en drie der voornaamste ingezetenen. Voor dezen raad kwamen alle zaken van politie en justitie, wat zeer druk werk gaf. Ingezetenen waren er moeilijk voor te vinden. Men werd Luthersch om aan deze voor Gereformeerden weggelegde corvée te ontkomen $^{2}$ ). De drie militaire leden werden op deze wijze onttrokken aan hun eigenlijk werk, daargelaten, dat zij moeilijk de meest aangewezen handhavers van politie en justitie konden worden geacht, terwij1 zij op deze wijze als "raden van policie” verbeeldende de hooge regeering van het eiland, orders aan zichzelf gaven. Ook deze leden bleken op hun lidmaatschap weinig gesteld.

Omtrent de door hen gewenscht geachte verandering schrijven Commissarissen het volgende:

,$\ldots$. de politieke regering behoort altijd geschikt te zijn naar het locaal der plaatse, en naar den aard der inwooners, en wanneer men dit met opzigt tot het eiland van Curaçao in acht neemt, zal men bevinden, dat de burgerlijke vrijheid aldaar nauwer beperkt dient te worden dan wel elders"'. Wat den aard der plaats betreft, wordt erop gewezen, dat Curaçao niet zoozeer als eene handelsplaats moet worden beschouwd en gewaardeerd,

1) Zij zouden daarmee buitendien buiten hunne opdracht zijn gegaan. Ook hadden zes personen ex officio zitting, wier ambt ter dispositie van de West-Indische Compagnie stond.

2) Hamelberg, t.a.p. bl. I56. 
als St. Eustatius, maar meer als de eenige veilige haven, die de Staat in West-Indië heeft, die als zoodanig van zooveel belang is, dat „al konde de commercie van Curaçao van geen het minste voordeel zijn, en dat de behouding van hetzelve den lande veel gelds koste, zoude men nogtans vermeenen, dat die plaats van te veel aangelegenheid is, om dezelve immer te verwaarlozen, maar daaruit volgt dan ook van zelfs dat deszelfs gouvernement moet kunnen strekken tot verdeediging en beveiliging, en dus zooveel als doenlijk is moet gelijkgesteld worden met een frontiervesting te lande, en welk een gouverneur zeer veel gezags moet hebben, en in de zaken van policie niet door de burgerlijke regering moet kunnen worden verhinderd".

De aard der inwoners eischt hetzelfde. De voornaamste families wonen op hunne plantages, de ambtenaren en bedienden van de Compagnie in of achter het fort, terwijl in de stad eene menigte van Joden, varensgezellen, Spanjaarden, volk van allerhande natiën, vele vrije mulatten en negers en slaven wonen, ,en daaruit kan men nagaan of eene strikte order en policie aldaar noodzakelijk is". In de derde plaats wijst in dezelfde richting de losbandigheid der negers. „Doordien dit eiland een zeer oude colonie is, heeft de vermenging van de couleuren tot zoo een hogen graad plaats gevonden, dat geen zes familien op het eiland geteld kunnen worden, welke niet aan lieden van de couleur vermaagschapt zijn; men vindt dus ook een menigte van mestiezen, castiezen en mulatten, zooals ook veele vrijnegers en vrije meiden, al hetwelk de zoo hoog noodzakelijke band van discipline geheel en al heeft verbroken ; ook kunnen de ondergeteekenden getuigen in geen eene colonie geweest te zijn, waar de negers zooveel stoutmoedigheid bezitten dan in Curaçao, en het voorbeeld aldaar is niet raar, dat een neger de hand heett gelegd op een blanke, en denzelven gekwetst, eene daad, welke in de landbouwende colonien zonder genade met het rad wordt gestraft. Hier komt nog bij, dat men alhier heeft ingevoerd de gewoonte, welke men zeker van de Spanjaards heeft overgenomen om de meeste negers te doopen, vooral bij de Roomschgezinden; was een neger nu vatbaar voor een behoorlijk onderwijs in den Godsdienst en wierd hetzelve dan aan hem te koste gelegd, zoude het eene prijzenswaardige zaak zijn en kunnen strekken om zijne zeden te beschaven, maar op den voet waarop het tegenwoordig is, kan het nergens 
toe dienen, dan om den neger eene superstitie meer te geven, waarvan hij uit den aard zoo rijkelijk is voorzien, hem hoogmoedig te maken, en in cas van rupture met de Spanjaarden gevaarlijk te doen zijn".

$\mathrm{Om}$ in deze eischen te voorzien is noodig: een directeur of „opperhoofd” met onbepaalde macht „omtrent al hetgeen de policie betreft", en niets met den raad te maken hebbende ; verder eene behoorlijke administratie van de justitie, waarbij de kleine zaken worden behandeld door eenen "kleinen raad”, bestaande uit den directeur en vijf burgerraden met den secretaris. De Wees- en boedelkamer behoort op gelijke wijze herzien te worden als voor Essequebo en Demerary geraden is.

Het kan moeilijk ontkend worden, dat Commissarissen heel wat uitvoeriger zijn geweest in hunne opsomming der klachten over het bestuur dan in de omlijning hunner middelen tot herstel.

Eene afzonderlijke bespreking is gewijd aan de Financiën der kolonie.

Van I784-I788 (inclusief) hebben de inkomsten bedragen $f$ 38r.860 "I4"-, waaronder gerekend zijn de recognitie- en waaggelden, de vijftigste penning en de accijns, placaat-, paspoort- en lastgelden, de plantages, windmolens, en wat Aruba en Bonaire opgeven. De uitgaven hebben bedragen $f 744.206$,2"'-, zoodat er over deze jaren een tekort is geweest van $\left.f 362.345,8^{\prime \prime}-1\right)$. In vroeger jaren is veel geld getrokken van het eiland, vooral vóór den laatsten oorlog tusschen de Republiek en Engeland, maar in dien oorlog zijn veel kosten gemaakt, o.a. zes ton gouds voor de oprichting van een vrijcorps.

De plantages van de Compagnie zijn verhuurd voor $f$ I7.000 behalve die, waarop de ambtenaren van de Compagnie wonen, zooals Hato met 99 slaven, „hetwelk alleen wordt gehouden ten dienste van den directeur [als diens buitenverblijf], die daarvan alle de middelen geniet, en de Compagnie daartegen de schade"'. Er wordt ook op onverantwoordelijke wijze geld uitgegeven. Zoo hebben Commissarissen Hato „hegt en sterk" bevonden, doch na hun vertrek is het op kosten der Compagnie ,vermaakt”. Op Bonaire heeft de Compagnie

1) Hamelberg, t.a.p. bl. 2ro geeft voor I740 nog een batig slot van Ps. I0780.I.5 op. 
323 slaven. Van dit eiland worden „provisien van brandhout, kalk, vee en diergelijken gehaald" met een vaartuig, dat per jaar $f 90.000$ kost, terwijl ook het eten der slaven moet gekocht worden, „uit hoofde dat de grond zoo weinig is gecultiveerd".

En dan nog deze klacht : men koopt mais als die schaarsch en duur is, en vergeet dit te doen als zij goedkoop is ; men zet de gouvernementsslaven aan minder noodzakelijk of zelfs noodeloos werk, en huurt dure slaven voor wat noodzakelijk gebeuren moet.

Den slechten toestand der financiën wijten Commissarissen niet alleen aan onverantwoordelijk beheer der gelden maar ook aan verwaarloozing der inkomsten. Het hoofdgeld der slaven was sedert I784 niet meer gevorderd, omdat men het ,niet had durven innen", en daarvóór, van I Juli I772-I Juli I784 bracht het niet meer dan $f$ 5I.900 op, hoewel van elke slaaf een halve Pezos of een gulden Hollandsch ${ }^{1}$ ) moest betaald worden, en in I789 I3000 slaven opgegeven worden ${ }^{2}$ ). Voor eenige jaren bracht dit hoofdgeld het dubbele op. Nu kunnen wel de "plantagieslaven of veldnegers" niet zooveel opbrengen als in eene landbouwende kolonie, maar vele slaven zijn arbeiders en varenslieden ,en bovendien is het getal van huisslaven tot eene bovenmatige luxe vermeerderd".

Nog veel meer is de Compagnie te kort gedaan met de recognitie- ${ }^{3}$ ) en accijnsgelden. In I788 is hierin alleen $f 94.000$ gefraudeerd. De opbrengst was toen $f 55.6 \mathrm{r} 3$, de uitgaven beliepen $f$ II 4.500, zoodat er op deze dienst een tekort was van $f$ 58.000, wat een batig saldo van $f 35.000$ had kunnen zijn $\left.{ }^{4}\right)$.

1) Simons t.a.p. zegt: twee gulden, en vergeet wellicht, dat het in 1764 op de helft verminderd was. Hamelberg t.a.p. bladz. 208 .

2) Zie Hamelberg, t.a.p. bladz 208, die meedeelt, dat het hoofdgeld in den loop der jaren niet meer geheven werd van het werkelijk getal slaven maar volgens een kohier, naar gissing en met de noodige „consideratie" opgemaakt.

3) Een zeker percentage van de waarde van alle in Hollandsche schepen aangebrachte en uitgevoerde goederen en ook van alle goederen, voor doorvoer aangebracht van de West-Indische eilanden. Hamelberg t.a.p. bladz. 206.

4) Dit lijkt heel veel, als men het vergelijkt met het cijfer, dat Hamelberg t.a.p. bladz. 209 opgeeft als opbrengst van deze gelden over de eerste helft van I740: Ps. 9429.6. 
Aanbevolen wordt de oprichting van een douanekantoor ,zonder de commercie te benadeelen". Wel zijn er voor het tegengaan van fraude "beëedigde visitateurs" voor de inkomende schepen, maar deze ambtenaren worden zoo slecht betaald, „,dat (zij) onmogelijk een sober bestaan daarvan zouden kunnen hebben, en dat men dezelve niet te min met garnituren van gouden gespen ziet wandelen".

Er zouden ook nog wel andere inkomsten te vinden zijn, meenen Commissarissen, die begrijpelijkerwijs ook ingenomen zijn met de I \% Kaapvaartkas. „Eene kas vind men op dit eiland, welke in een goede staat is, namentlijk de zoogenaamde I Pct. of zoogenaamde caapvaartcassa, welker batig saldo eene somma van ruim $f$ I 90.000 bedraagt", en waarvan de gelden op verschillende hypotheken zijn uitgegeven $\left.{ }^{1}\right)$.

Het verdere van het rapoort bespreekt den ,staat en vrugtbaarheid van Curaçao”, het ,,commerciewezen”, het „formeeren van een wetboek", de ,behandeling der negers door hunne meesters", godsdienst en defensiewezen. Ook dit is niet van belang ontbloot.

\section{Staat en vrugtbaarheid van Curaçao.}

„De zoogenaamde plantagien bestaan meestal in grond tot de culture van mais aangelegd, welke alleen kan dienen tot onderhoud van de slaven, en de maisstokken voor het vee in den droogen tijd, doch die gronden kunnen nimmer eene genoegzame voorraad opleveren, zijnde zoodanig planter, den een meer, den anderen minder, meest altijd verpligt een aanzienlijken vooraad bij te kopen, om zijne slaven te onderhouden ; verders vindt men alhier op sommige plaatsen in het beneden quartier eenige stukken grond, beplant met zuiker en catoen, dog de geringe quantiteit, welken aldaar van die producten wordt geteeld, maakt dat hetzelve geen naam verdiend, hoezeer die andersints zeer goed van soort zoude zijn, vooral de catoen, welke tot veel hooger prijs word gekogt dan die van Demerary, het

1) In I725 was dit recht op nieuw ingesteld ter bestrijding van de uitrusting van commissievaarders en van het zeeliedenhospitaal. Hamelberg. t, a. p. bladz. 206 . 
meeste voordeel, hetwelk mitsdien van die plantagien te halen is, bestaat in de tuinvrugten en den aankweek van allerhande vee, vooral wanneer dezelve wat nabij de stad of hoofdplaats zijn gelegen, en de planter dagelijks zijne waaren derwaarts kan zenden om door zijne negers te doen verkoopen".

Het eiland is zoo rots- en klipachtig, „dat men maar weinige plaatsen vindt waar eene genoegzame couche van aarde is, die tot den landbouw kunnen worden gebruikt" en de langdurige droogten maken, dat ,een planter in een jaar dikwijls meerder verliest dan hij in zes jaren kan verdienen".

| Men kan hieruit besluiten, „dat Curaçao op zichzelven een dorre klip is, maar dat het behoort aangehouden te worden, voornamentlijk voor zijne haven.... en in de tweede plaats van zijne commercie...."

\section{Het Commerciewezen.}

De handel is zeer wisselvallig, afhankelijk van vrede en oorlog. Nu de handel van Spanje naar hare West-Indiën vrij is, zijn alle kusthavens gesloten en kan Curaçao alleen handel drijven met hen, die hunne waren van de Spaansche kust naar Curaçao brengen, en dit moet zooveel mogelijk begunstigd wor$\left.\operatorname{den}^{1}\right)$. Verder wordt hier verwezen naar een niet annwezig afzonderlijk rapport over dit onderwerp.

Voor commercieele of zeezaken moet eene korte wijze van procedeeren worden ingevoerd, daar „het minste delay of tijdverzuim een groote stremming moet toebrengen aan de commercie, zooals op Curaçao gevoerd kan worden, te weten een sluikhandel, alzoo het voor een sluikhandelaar van het uiterste belang is, om zich zoo spoedig doenlijk wederom weg te baanen van de plaats, waar hij zijne waren heeft aangebragt, en daarentegen andere goederen heeft ingenomen".

\section{Formeeren van een wetboek.}

Verwezen wordt naar het hieromtrent betreffende Essequebo en Demerary opgemerkte „alleenlijk met dit onderscheid, dat het gedeelte, rakende de vrije Indianers of naturellen van den

1) Zie voor dezen handel vice versa J. H. Hering t. a. p. 
lande alhier minder te pas komt, alzoo dezelve, uitgezonderd drie of vier afgeleefde menschen, op het eiland Curaçao niet meer gevonden worden en op Bonaire en Aruba zijn ook weinige van dezelve meer over".

\section{Behandeling der negers door hunne meesters.}

„Wanneer men de losbandigheid en stoutmoedigheid der slaven in dit eiland in acht neemt, zoude men in den eersten opslag geloven, dat dezelve volkomen vrij waren en dat de meesters niets over dezelve te zeggen hadden, doch bij een nauwkeurig onderzoek zal men bevinden, dat slaven aldaar van veel ongelukkiger conditie zijn dan de slaven op de vaste kust van Guyana $^{1}$ ), want doordien dit eiland geene genoegzame mondbehoeftens opleverd en het onderhoud der slaven aan den meester kostbaar valt, zoo volgd daaruit dat die mondbehoeftens met alle mogelijke spaarzaamheid worden uitgedeeld, ja zelve is het niet zonder voorbeelden, dat in schaarsche en dure tijden negers aan gebrek van voedsel zijn omgekomen; daarvandaan is de barbaarsche gewoonte ingevoerd, dat een oude en verminkte slaaf door zijn meester word vrijgegeven, welke zoogenaamde gunst voor zijn gedane diensten hem noodwendig aan gebrek moet blootstellen, indien hij met bedelen zijn kost niet kan verdienen, daarvandaan is het gebruik ingeslopen, dat zeer vele slaven de vrijheid hebben, nu buiten het oog van hunnen meester of opzieners te gaan werken, negotie te doen, te visschen of iets dergelijks, ten einde hun kost te verdienen, mits zij slechts eene zekere bepaalde somma 's weekelijks, opbrengen, en waarvan dus het gevolg is dat zij niet onder genoegzame discipline zijnde, het nodige ontzag verliezen, en zich aan diefstal schuldig maken, wanneer zij daartoe gelegenheid kunnen vinden"'.

„Het straffen met zweepslagen is alhier niet in gebruik; wanneer een neger publicq wordt gestraft, geschiedt zulks met eene geeseling, hetgeen watapána genoemd wordt, zijnde een zeker soort van riet $^{2}$ ), de huisstraffen geschieden met bullepeesslagen, doch zelden tot een bovenmatige graad".

1) Dat klinkt wel wat anders dan Hamelberg t.a. p. bladz. 212, zegt over „de goede behandeling", waaraan hij den slechten naam wijt, die de Curaçaosche slaven op de wereldmarkt zouden gehad hebben.

2) Dividivi. Zie Encyclopaedie van Nederlandsch West-Indië sub voce. 
Wat over den godsdienst gezegd wordt, is van geen beteekenis.

\section{Defensiewezen.}

Hierover schijnt een afzonderlijk rapport van den inspecteur Daniel Creefts bijgevoegd te zijn. En verder wordt daarvan het volgende gezegd : De haven van Curaçao is zeer gemakkelijk te verdedigen, maar als de vijand elders geland is en bezit van het eiland heeft genomen, dan is stad, fort en haven spoedig te vermeesteren, als de vijand niet onderweg tegengehouden wordt $\left.{ }^{1}\right)$.

De cavallerie, waarvan de manschappen alleen gebruikt werden "tot het doen van een boodschap" zou gemist kunnen worden; het zijn oude lieden, die hiertoe behooren, en te voet gaan, tenzij zij daarvoor te oud zijn, dan gaan zij op een ezel. Maar als zij van een buitenpost een schip moeten rapporteeren aan het hoofdfort is het schip meestal al lang in de haven als de tijding komt.

De „bosch schutters of artilleristen, die op de buitenforten zijn, zijn ook meest alle oude en onbekwame menschen.

„Onder de soldaten zelve bevinden zich mede zeer veele oude gebrekkige, ja verminkte manschappen".

Vele defensiewerken zijn met groote kosten zonder eenig nut aangelegd. Zoo heeft men vóór de batterij van het hoofdfort aan den zeekant de Compagnies-magazijnen gebouwd, die hier door geheel en al aan het vuur van den vijand zijn blootgesteld, en „waardoor men zijn eigen canon ter verdediging niet kan gebruiken, of men zoude eerst die magazijnen tot eene zekere hoogte moeten doen omverre schieten".

Hier eindigt het verslaggevend gedeelte van het rapport. De slotsom zal niemand verwonderen ; deze luidt, dat „direkteur en Raaden.... hun plicht in allen deelen hadden verwaarloosd en zelve oorzaak waren van hun gering gezag"'. Commissarissen hebben hun dit bij het afscheid nemen nog eens goed onder het oog gebracht in ,eene zeer ernstige aanspraak en aan-

1) Dat was in 1713 gebleken bij de brandschatting van Cassart. Hamelberg t. a. p. bladz. II9 e.v. In I804 gelukte het wel den Engelschen commandant J. Bligh tegen te houden. Euwens t. a. p. 
maning". Waarschijnlijk hebben directeur en raden daarover een oogenblik "paf” gestaan, en wisten zij niet wat te antwoorden, althans toen Commissarissen reeds ingescheept waren, zonden zij nog hunnen secretaris aan boord om zich over die afscheidsrede te beklagen.

Commissarissen verhelen echter aan het slot niet, dat ook het bestuur uit het vaderland reden tot klachten geeft. Een voorbeeld wordt hiervan genoemd. Het „ontvangers en boekhouders comptoir" is in zeer goede orde bevonden, maar tal van pretentiën ten laste van particulieren, waarover processen waren ontstaan, blijven in revisie hangen, ,doordien de compagnie dezelve niet behartigd en de ontvangers niet in staat zijn of gesteld worden die procedures te volvoeren".

$\mathrm{Na}$ de mededeeling, dat zij den roden December, dus na een verblijf van ruim drie maanden, van Curaçao vertrokken zijn, sluiten Commissarissen hun rapport met deze woorden:

„De ondergeteekenden hebben bij hun vertrek van Curaçao niet hetzelfde genoegen mogen smaken hetgeen zij te voren te Essequebo en Demerary hadden genoten, namentlijk van de meeste lieden der regeering en amptenaren tevreden gesteld en dezelver genegenheid te hebben verworven; dan zulks belet niet dat zij de vrijheid moeten nemen Curaçao en deszelfs inwooners in de gunstige gedachten van Uwe Hoogheid aan te bevelen, als zijnde een plaats van het allergrootste aanbelang voor de Nederlandsche scheepvaart, en welke voor de commercie van nut kan zijn"'.

II Februari I79I is het rapport gedateerd. Er mag aan getwijfeld worden, of het veel invloed heeft gehad op de veranderingen in het bestuur der kolonie, nog in datzelfde jaar genomen tegen het afloopen van het octrooi der West-Indische Compagnie op 3I December I79I. Bordewijk, die de geschiedenis dezer verandering uitvoerig beschrijft, ${ }^{1}$ ) spreekt er niet van. Trouwens de toen genomen maatregelen waren slechts voor korten tijd. Negen jaren later ging Curaçao voor het eerst , verloren voor Nederland.

Dordrecht, September I9r9.

1) Mr. Dr. H. W. C. Bordewijk, onstaan en ontwikkeling van het Staatsrecht van Curafao, 's Gravenhage, I9II, bladz. 5--20. 